\author{
Nataliya Antonyuk, \\ Ph.D., Sumy State University, Ukraine \\ (D) ORCID ID, /0000-0001-8610-3219 \\ email: n.antoniuk@finance.sumdu.edu.ua \\ Iryna Plikus, \\ Ph.D., Sumy State University, Ukraine \\ (iD) ORCID ID, 0000-0002-0657-7260 \\ Mohammad Jammal, \\ Ph.D., The British University in Dubai, United Arab Emirates \\ (iD) ORCID ID, 0000-0002-0088-3523 \\ Correspondence author: n.antoniuk@finance.sumdu.edu.ua
}

\title{
HUMAN CAPITAL QUALITY ASSURANCE UNDER THE CONDITIONS OF DIGITAL BUSINESS TRANSFORMATION AND COVID-19 IMPACT
}

Abstract. This article addresses human capital quality and development analysis under the digital transformation and economic changes effected by the COVID-19 pandemic. The primary goal of this study is to justify the theoretical and methodological provisions for developing an environment of innovation, assuring the digitalization of society through innovation activity of economic entities and human capital development by ensuring its quality under the COVID-19. The theoretical and methodological basis of the study involved the systematic approach, comparative method, statistical analysis. The foresight principles were applied for quantitative and qualitative monitoring of innovation and human capital policy measures through preventive work with information and official documents concerning the digital transformation, development of innovative economy, and human capital. In the study frameworks, the authors analyzed the scientific sources addressing the investigated topic. The search for relevant publications was conducted in the scientometric databases Google Scholar, Web of Science, EBSCO, and others. For comparing the frequency of search requests under the determined research keywords, this study involved the instruments of the online search engine Google Ngram Viewer. The sources of information are the European Union website and the State Statistics Service of Ukraine, analytical reviews, reports, and forecasts by leading consulting companies. Based on the treatment of the world forecasts and analytical reviews, the study determined the development directions of an innovative economy and human capital considering an educational and scientific policy. The main study results stated the necessity to improve the human mental capacity due to keeping the work and rest arrangements. Therefore, it needs pharmacological recommendations and other measures to improve mental capacity as key criteria for human capital quality. The study results were validated within the framework of expert discussions at scientific and practical conferences and round tables with representatives of leading enterprises and universities. The authors developed several proposals to deal with identified problems and challenges.

Keywords: human capital, human potential, quality, hygiene, COVID-19, cognitive capacity, digitalization, innovative development, education, business.

Introduction. Nowadays, the world's innovative economies provide 70-90\% of GDP, which depends on human capital quality. Based on the analysis of 192 countries, the experts from the World Bank concluded that human capital provides at the average rate of $64 \%$ of total wealth, the physical capital $16 \%$, and natural capital - 20\%. In Germany, Sweden, Japan, the human capital ensures $80 \%$ of national wealth. In the case of the USA national wealth structure, production assets provide $19 \%$ of total wealth, natural resources $-5 \%$, and human capital $-76 \%$. Further, in Ukraine, the share of national wealth provided by human capital is about $53 \%$ (World Bank, 2017). According to the World Bank, human capital

Cite as: Antonyuk, N., Plikus, I., \& Jammal, M.. (2021). Human Capital Quality Assurance under the Conditions of Digital Business Transformation and COVID-19 Impact. Health Economics and Management Review, 3, 39-47. http://doi.org/10.21272/hem.2021.3-04

39 
creates about $2 / 3$ of the national wealth of countries. Besides, it is the main driving force for innovation and economic development (Puschulina et al., 2018).

Therefore, Ukraine has to develop human capital to accelerate innovative economic growth, particularly ensuring a sufficient level of quality under hygienic, educational, and intellectual requirements. Besides, it is essential to improve the system of human capital formation addressing the innovative development of society, i.e., the ability to quickly generate, disseminate and use the knowledge and technologies in the interests of economic growth, welfare society, and the competitiveness of domestic enterprises and country. Following the findings in the research (Maslennikov et al., 2016), the innovative economy needs about $60 \%$ of economically active citizens with higher education. It is primarily determined by the digital transformation of business, which requires particular competencies from professionals occupying a key position in the labor market. Moreover, these competencies ensure the formation of the innovative environment of economic entities.

Following the above, this study aims to substantiate the theoretical and methodological provisions of the environment of innovation, which provides social digitalization due to economic innovations and human capital development by ensuring its quality adequate to current economic conditions, including the COVID19 pandemic.

Methodology and research method. The theoretical and methodological basis of the study relies on a systematic approach. It involves comparative and statistical analysis. Besides, the foresight principles were applied for quantitative and qualitative measuring innovation and human capital monitoring policy through preventive work with information and official documents concerning the digital transformation, development of innovative economy, and human capital. Besides, the publications on the research topic were analyzed. The search for relevant papers was carried out in Google Scholar, Web of Science, EBSCO, and other bibliographic databases.

For determining the research directions, this study involved the toolkit of Google Ngram Viewer (GNV). The obtained results allow comparing the frequency of search queries for research keywords.

The data for the empirical analysis is retrieved from the statistical databases of the European Union and the State Statistics Service of Ukraine, analytical reviews, reports, and forecasts of leading consulting companies. This study analyzed the materials of world forecasts and thematic analytical reviews to screen the development of innovative economies and human capital considering the educational and scientific policies. The study results were validated through expert discussions at scientific and practical conferences and round tables with leading enterprises and universities representatives. In turn, the generalized conclusions were the basis for proposals concerning the identified problems and challenges.

Results. The systematization of theoretical findings allowed determining that:

- digitalization does not mean the automatic development of the digital economy. The basis for its growth has been created for several decades. Acceleration of scientific and technological progress has led to digitalization that develops the methodology for the use of IT and information resources in business;

- under digitalization, the primary sources for information growth are digital platforms, the Internet of Things, and social networks (business relationships transform into digital (carrying out in an electronic environment through constant real-time processing of digital data; search and selection of the customer on digital Internet platforms, that displaces email, online shopping, and telephony out of business communications). The most popular digital platforms have transformed some markets into digital (services are provided and consumed in electronic services, such as Booking.com, Uber, etc.). In this case, IT provides the business with more intensive and fast communications, better automation of interactions with the external environment, and online processing of information resources compared to the previous stages of IT application (automation and informatization). Digitalization creates new business opportunities that could be realized through the development and implementation of innovations; 
- the prerequisite for the digital transformation of society is developing an innovative environment and innovation that ensure its development through innovative business activities;

- the rapid proliferation of digital technologies makes citizens' digital skills (competencies) key, among other skills. Besides, the ability of professionals to innovate and their competencies must be considered when creating an innovative environment that will allow businesses to access new types of resources;

- economic development is provided by innovations and human resources.

Figure 1 presents the analysis results of the popularity of the definitions «economy», «human resources», «innovation», «education» in English-language publications for 2010-2019.

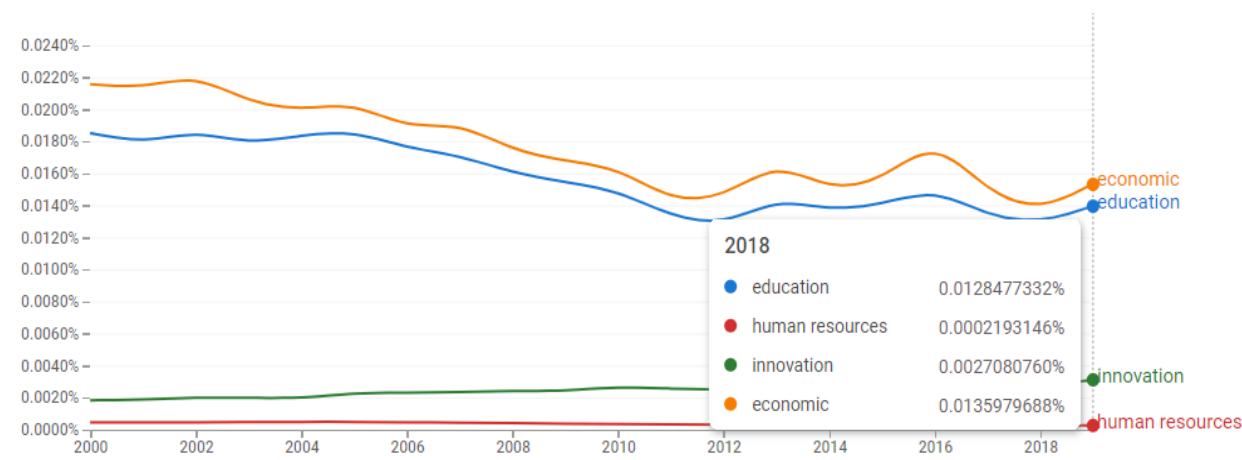

Figure 1. The popularity of the keywords «economy», «human resources», «innovation», "education» in English-language publications for 2010-2019

Sources: developed by the authors based on the GNV data (2021).

Summarizing scientific data sources showed that researchers pay significant attention to the relationship between public education as one of the criteria for human capital quality and economic development. Thus, the findings of bibliometric analysis using the toolkit of InterDisciplinary Research, Network Workbench Tool, SciMAT, showed that scientific discussions increasingly focus on issues of investment in education and return on them, the relationship between education and economic growth, development of human capital and its undercapitalization, professional competencies, education, and staff development.

The scientists consider the concept of human capital based on the following interrelated features: 1) human capital is an integral part of human resources and a transformed form of human potential; 2) human resources and potential could be transformed into human capital in certain internal and external conditions. Based on the above, there is a need to articulate and distinguish the concepts of «human capital», «human resources», and «human potential» from a context and functional point of view.

Some scientists consider the concepts of «human capital» and «human potential» to be identical. In turn, both cases address the person with certain health, education, breeding, motivation, etc. However, the concept of «human capital» is closer to economic activity, while «human potential» - to the sociological concept. Based on the above, some experts believe that human potential is a combination of human capital, the social and economic conditions for its formation, development, and use. The concept of «human capital» includes «human potential» because it considers a certain person with particular health conditions, breeding, education, behavioral motives. Assuming that «capital» is main in «human capital», then a person is a particular object. Noteworthy here that investments make the person only a potential 
economic object with a specific value. Thus, the person would be capital when he/she becomes a subject of economic activity, which means that investments should begin to profit.

It stands to mention that human potential transformation in human capital needs appropriate social, economic, organizational, and innovative prerequisites. Besides, it could need the employees' motivation to use their human potential. Thus, human capital is considered to be a system of characteristics that determine a person's ability to work and require certain investments. On the other hand, human potential is the ability, possibility, and need to work. In turn, the person's ability to work is determined primarily by follows: etc.);

1) the amount of human capital (innate abilities, talent, health, acquired knowledge, career summary,

2) the need to work as the system of his values and preferences (motivation, interests, the degree of activity, etc.);

3) the possibility of full-fledged and creative work depends on the quality of human life.

Human potential has strategic properties and could be considered as a strategic element of human resources since it represents a potential for development and adaptation to ever-changing conditions. In the economic context, human resources are usually defined as available specialists (personnel), reserves of personnel with professional, physical, and intellectual abilities used to ensure public reproduction. Herewith human resources could be represented as a combination of human potential and labor resources.

The mentioned above shows the relationship and interaction between the concepts of «human resources», «human capital», and «human potential». The sources and base of human capital are human resources and potential. Thus, human capital takes the form of:

1) human potential - its structure includes physical, emotional, and rational potential, as well as explicit and implicit human abilities;

2) human resources - the social component of the human personality, which determines the relationships in public production.

Figure 2 demonstrates the process of human capital development. This process visualizes a spiral movement, where each new whorl is a new stage of development.

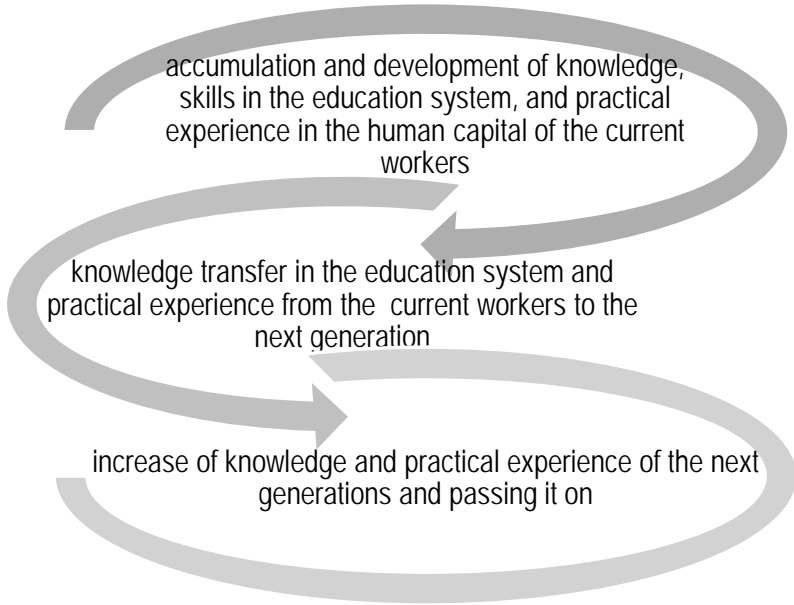

Figure 2. The human capital evolution process

Sources: developed by the authors. 
The analysis of the main conditions for formating and quality criteria for assuring the human capital in Ukraine showed that the R\&D/GDP intensity remains critically low. In 2019, more than 17 billion UAH were spent on R\&D in Ukraine. Table 1 shows the government provided the biggest finance support $-38.3 \%$, then domestic customers - 28.1\%, foreign sources - 22.3\%, and own funds - $10 \%$ (Pysarenko et al., 2019).

Table 1. R\&D expenditures by activity sectors in the view of scientific branches in 2019 (UAH million)

\begin{tabular}{|c|c|c|c|c|c|c|c|}
\hline \multirow[t]{2}{*}{ Subject area } & \multirow[b]{2}{*}{$\begin{array}{l}\text { R\&G } \\
\text { expenditures, } \\
\text { total }\end{array}$} & \multicolumn{6}{|c|}{$\begin{array}{l}\text { Including according to the activityThe share of financing for } \\
\text { sectors } \\
\text { science from the general } \\
\text { expenses on R\&D of } \\
\text { activity sector, \% }\end{array}$} \\
\hline & & 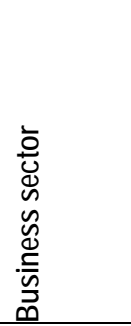 & 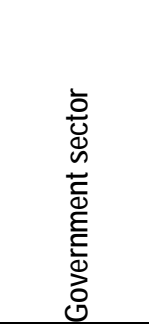 & 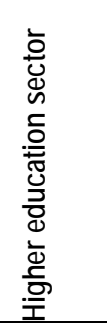 & 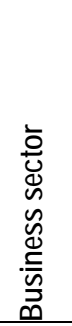 & 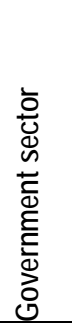 & 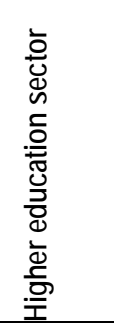 \\
\hline Natural & 3755,9 & 1040,3 & 2330,6 & 384,9 & 10,2 & 39,0 & 36,4 \\
\hline Technical & 10925,9 & 9022,4 & 1513,9 & 389,7 & 88,2 & 25,4 & 36,9 \\
\hline Medical & 546,6 & 50,7 & 405,8 & 90,1 & 0,5 & 6,8 & 8,5 \\
\hline Agricultural & 963,3 & 81,5 & 813,1 & 68,6 & 0,8 & 13,6 & 6,5 \\
\hline Social & 742,4 & 5,3 & 633,6 & 103,5 & 0,1 & 10,6 & 9,8 \\
\hline Human & 320,5 & 25,2 & 275,4 & 19,9 & 0,2 & 4,6 & 1,9 \\
\hline Total & 17254,6 & 10225,4 & 5972,4 & 1056,7 & 100 & 100 & 100 \\
\hline
\end{tabular}

Sources: developed by the authors.

The statistical data analysis shows a critically low amount of financing of $R \& D$ in the medical sphere compared to technical and natural spheres. Public funding of R\&D in the medical sphere is less than in the higher education sector. In turn, it indicates the inefficiency of the state policy on ensuring the quality of human capital.

The next factor determining the development of human capital and the possibility of improving its quality is income level. Thus, the average wage in Ukraine in 2020 was $10340 \mathrm{UAH}$. Figure 3 demonstrates the average wages by the regions of Ukraine. Figure 4 shows its corresponding dynamics in 2020 and for the first 5 months of 2021. 


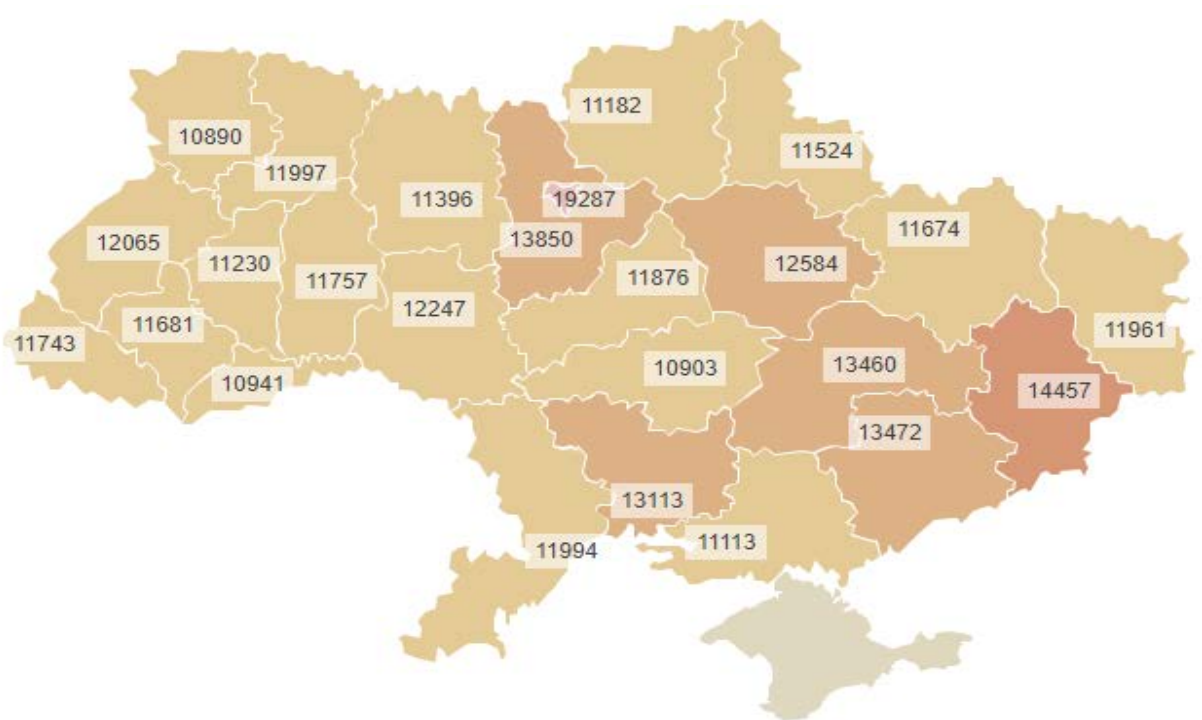

Figure 3. The average wage by the Ukrainian regions, May 2021

Sources: developed based on the (Minfin, 2021).

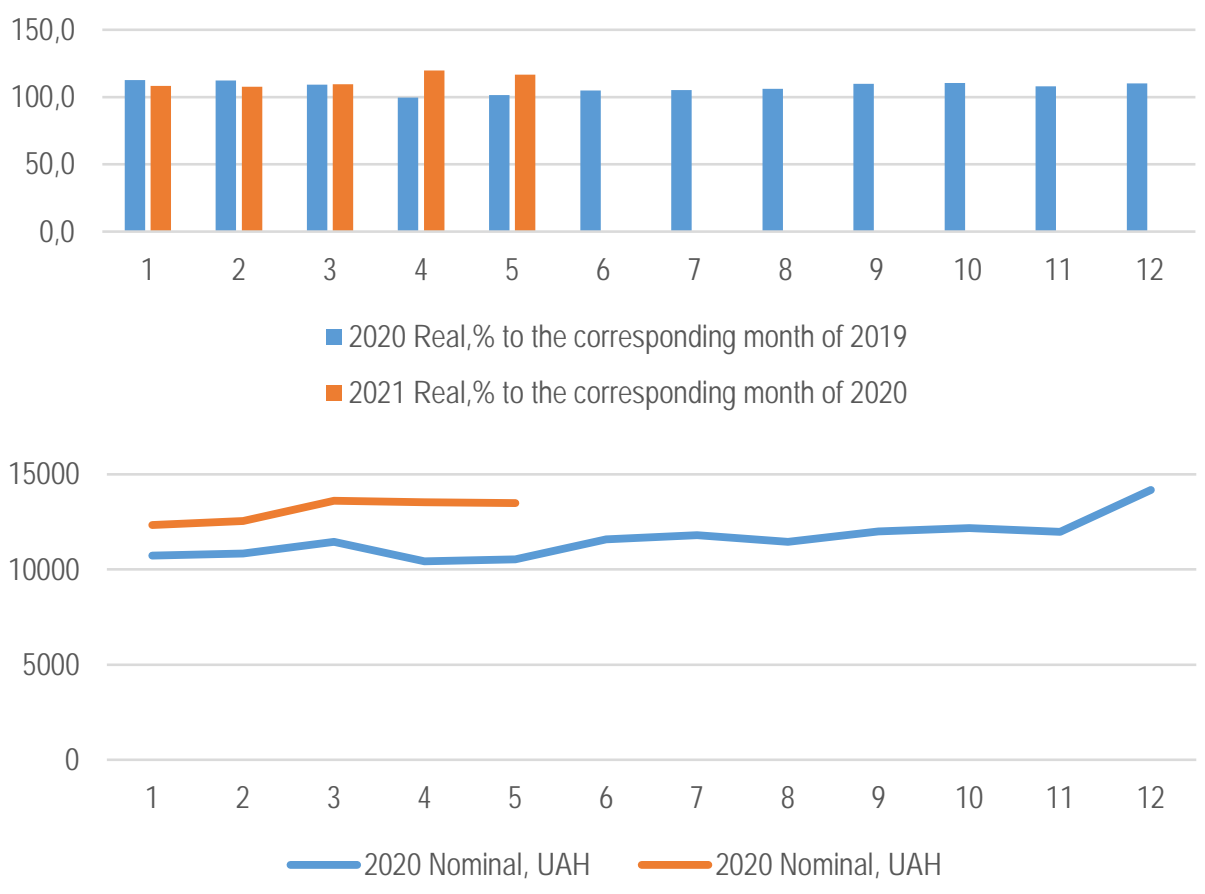

Figure 4. Changes in the average wage in 2020-2021

Sources: developed by the authors based on the (SSSU, 2021). 
Ukraine has less than $50 \%$ of the population of middle-class incomes and above (according to the World Bank standard, the middle class includes those who spend at least 10 dollars a day (24 Economica, 2021), which is about 8300 UAH per month). The research by the Razumkov think-tank showed that in 2016, 14.2\% represented the middle-class in Ukraine, and another $34.8 \%$ were middle-class peripheries (24 Economica, 2021) (Table 2).

Table 2. Ukrainian population by classes in 2016

\begin{tabular}{llllll}
\hline Class & Ukraine & West & Center & East & South \\
\hline Upper class & $1,3 \%$ & $0,9 \%$ & $1,7 \%$ & $0,8 \%$ & $1,4 \%$ \\
Middle class & $14.2 \%$ & $17,4 \%$ & $15,7 \%$ & $11,5 \%$ & $10,3 \%$ \\
Periphery of middle class & $34,8 \%$ & $33,5 \%$ & $36.6 \%$ & $30,5 \%$ & $36, ? 5$ \\
Lower class & $30,7 \%$ & $33,9 \%$ & $30,7 \%$ & $31,6 \%$ & $26,8 \%$ \\
Unclassified & $19,1 \%$ & $14,4 \%$ & $15,3 \%$ & $25,6 \%$ & $24,8 \%$ \\
\hline
\end{tabular}

Sources: developed by the authors based on (24 Economica, 2021).

According to the State Statistics Service, in 2019, more than two-thirds of Ukrainians considered themselves poor. Another third said they were not poor but did not belong to the middle class. In turn, only $1.1 \%$ of respondents considered themselves middle class, none of the rich the interviewed Ukrainians did not behave (Fig. 5).

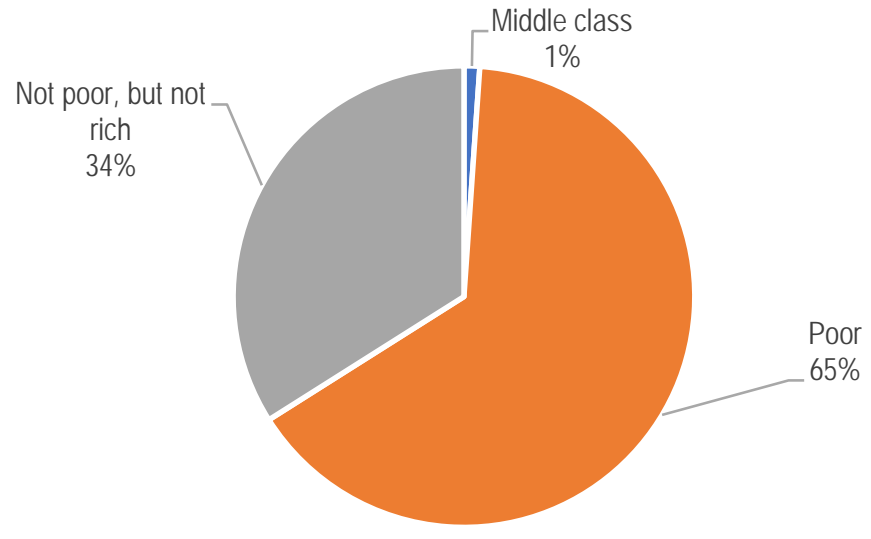

Figure 5. Households' self-assessment of income level in 2019

Sources: developed by the authors based on (24 Economica, 2021).

It stands to note that human capital formation is directly related to business. Thus, having received the already formed human capital, the business proceeds its transformation while using. At the enterprise, people get more than only practical experience and skills in a particular profession, but special knowledge and participation in activities that develop their potential. In the study (Tan, 2014), human capital is defined as the company's ability to derive future economic benefits from the potential of employees as typified in knowledge, skills, experience, innovation, creativity, loyalty, efficiency, ability to learn, motivation for improving skills, etc. This definition of human capital indicates that business development requires particular competencies from professionals to make the most efficient use of human capital for future economic benefits. 
According to the European Center for the Development of Vocational Education (Cedefop, 2014), the triggers of demand for professional competencies are employers involved in innovation. In turn, the OECD experts identify six groups of the most in-demand professional skills relevant to innovation as follows: digital literacy, research skills, subject knowledge, general competencies (such as critical thinking), soft skills (communication and teamwork), leadership (OECD, 2011; Nestulya, 2013; Nestulya and Nestulya, 2016; Nestulya, 2018). Noteworthy that subject knowledge remains relevant for the innovation sphere because success in this field depends more on the ability to sell the new solutions in the competitive environment.

Conclusions. The main study results stated the necessity to improve the human mental capacity due to keeping the work and rest arrangements. Therefore, it needs pharmacological recommendations and other measures to improve mental capacity as key criteria for human capital quality.

Further, it stands to note that hygiene concerns only human ergonomic abilities. However, this study proposes to focus on stimulating mental work (intellectual, cognitive, and creative).

At last, it is necessary to redirect the hygienic science. Environmental hygiene should focus on activating and maintaining the creative and cognitive properties of human capital and employees who can adequately and timely respond to all innovations in the digital economy, including the effects of digital transformation, which could cause misery and emotional stress.

Author Contributions: conceptualization, N. A.; methodology, I. P.; validation, N. A.; formal analysis, M. J.; investigation, N. A. and I. P.; writing-original draft preparation, N. A.; visualization, N. A.; project administration, M. J.

\section{References}

24 Economica. (2020). The middle class «in Ukrainian»: does it exist and who belongs to it. Retrieved from [Link]

Boronos, V., Plikus, I., \& Aleksandrov, V. A. N. (2018). Digital transformation of Ukraine: challenges of theory and practice in implementation of digital quality of life. Economic annals-XXI, (172), 38-44. [Google Scholar] [

Cedefop. (2014). European Centre for the Development of Vocational Training. Retrieved from [Link]

Maslennikov, Ye. Kuznyetsov, E., Safonov, Yu., Filippova S. (2016). Innovation economy: theoretical and practical aspects: monography, Issue 1/ eds Dr., as.prof. Maslennikova, Ye. Kherson: Grin' D.S., 854 p. [Google Scholar]

Minfin. (2021) Average salary in Ukraine. Retrieved from [Link]

Nestulya S. (2018). The concept of leadership as a basis for the formation of leadership competence of managers. Science Review. 7(14).

Nestulya, O. (2013). Fundamentals of leadership. Training of leadership qualities and practical skills of a manager. Lessons of prominent entrepreneurs: textbook. Kyiv: Znannya, 2013. 358 p. [Google Scholar]

Nestulya, O., \& Nestulya, S. (2016). Fundamentals of leadership. Scientific concepts (from ancient times to the middle of the XX century): textbook. Poltava: PUET, 277 p. [Google Scholar]

OECD. (2011). Education at a Glance 2011: OECD Indicators. Paris: OECD. Retrieved from [Link]

Plikus, I. Y., \& Antoniuk, N. A. (2020). The influence of digitalization on transformation processes on the labor market (Doctoral dissertation, Sumy State University). [Google Scholar]

Puschulina, O., Yurochko, T., Mischenko, M., \& Zhalilo, Ya. (2018). Human capital development: on the way to quality reforms. Razumkov's center, p.368. [Google Scholar]

Pysarenko, T., Kuranda, T., Kochetkova, O., Gavrys, T., \& Osadcha, A. (2019). Scientific and scientific-technical activity in Ukraine in 2019: Scientific analytical report, 109 p. [Google Scholar] 
N., Antonyuk, I., Plikus, M., Jammal. Human Capital Quality Assurance under the Conditions of Digital Business Transformation and COVID-19 Impact

SSSU. (2021). Wage in April 2021. Express edition. Retrieved from [Link]

Tan, E. (2014). Human capital theory: A holistic criticism. Review of educational research, 84(3), 411-445. [Google Scholar] [Link]

World Bank. (2017). Human Capital: The Greatest Asset of Economies on the Rise. Retrieved from [Link]

Наталія Антонюк, к.е.н.,, Сумський державний університет, Україна

Ірина Плікус, ORCID: к.е.н., Сумський державний університет, Україна

Мохаммед Джаммаль, к.е.н., Британський університет в Дубаї, Об`єднані Арабські Емірати

Забезпечення якості людського капіталу в умовах цифрової трансформації бізнесу та впливу пандемії COVID19

В статті представлені результати дослідження відносно розвитку та забезпечення якості людського капіталу в умовах цифррової трансформації суспільства та сучасних економічних реаліях, зумовлених наслідками пандемії COVID19. Сьогодні у провідних країнах світу від 70 до 90\% ВВП створюється інноваційною економікою, розвиток якої залежить, в першу чергу, від якості людського капіталу. Для розвитку інноваційної економіки Україна повинна розвивати свій людський капітал, зокрема забезпечувати достатній рівень якості за гігієнічними, освітніми, інтелектуальними критеріями, шляхом вдосконалення системи його формування, направленої на розкриття здібностей інноваційного розвитку суспільства, тобто здатності швидко генерувати, поширювати і використовувати потік знань і технологій в інтересах економічного зростання, зростання добробуту населення та конкурентоспроможності вітчизняних підприємств і держави. Мета дослідження визначена як обгрунтування теоретичних та методологічних положень формування інноваційного середовища, яке забезпечує цифрровізацію суспільства за рахунок інноваційної діяльності суб'єктів господарювання та розвитку людського капіталу иляхом забезпечення його якості адекватної сучасним економічним умовам, зокрема які виникли в результаті пандемії COVID-19. Теоретико-методологічна основа дослідження ґрунтується на системному підході в поєднанні з компаративним методом і аналізом статистичних даних, принципах Форсайта, який передбачає комбінацію кількісних і якісних методів моніторингу заходів політики в сфрері інновацій та людського капіталу через превентивну роботу з інформацією, а також вивченні офріційних документів щодо цифррової трансформації, розвитку інноваційної економіки та людського капіталу. Також було проаналізовано публікації з теми дослідження, пошук релевантних досліджень здійснювався серед наукових статей індексованих в профрільних базах даних Google Scholar, Web of Science, EBSCO ma інших. Розглядаючи інтерес науковиів до теми нашого дослідження скористалися можливостями Google Ngram Viewer (GNV), цей інструмент дослідження дозволяє порівнювати частоту пошукових запитів по ключовим словам дослідження. Емпіричну базу дослідження становлять статистичні дані Європейського Союзу та Державної служби статистики України, аналітичні огляди, звіти та прогнози провідних консалтингових компаній. За матеріалами світових прогнозів і тематичних аналітичних оглядів в дослідженні проведено скринінг розвитку інноваційної економіки, людського капіталу з урахуванням освітньої та наукової політики. Результати дослідження пройшли валідацію в межах експертних обговорень на науково-практичних конфьеренціях та засіданнях круглих столів за участю представників провідних підприємств та університетів. На їх основі були розроблені пропозиці в якості відповідей на виявлені проблеми та наявні виклики.

Ключові слова: людський капітал, людський потенціал, якість, здоров'я, гігієна, COVID-19, когнітивні здібності, діджиталізація, інноваційний розвиток, освіта, бізнес. 